九州大学学術情報リポジトリ

Kyushu University Institutional Repository

\title{
Production of Biogas from Olive Pomace
}

AYADI, Manel

IMT-At lant ique

AHOU, Sylvestre

IMT-At lant ique

AWAD, Sary

IMT-At lant ique

ABDERRABBA, Mane $f$

LMMA, Université de Carthage

他

https://doi.org/10.5109/4055224

出版情報：Evergreen. 7 (2)，pp.228-233，2020-06. 九州大学グリーンテクノロジー研究教育センター バージョン：

権利関係 : 


\title{
Production of Biogas from Olive Pomace
}

\author{
Manel AYADI ${ }^{12 b}$, Sylvestre AHOU ${ }^{1}$, Sary AWAD ${ }^{1 a, *}$, Manef ABDERRABBA ${ }^{2}$, \\ Yves ANDRES ${ }^{1}$ \\ ${ }^{1}$ IMT-Atlantique, GEPEA UMR CNRS 6144, Nantes, France \\ ${ }^{2}$ LMMA, Université de Carthage, Tunis, Tunisia \\ * Corresponding author: sary.awad@imt-atlantique.fr ;
}

(Received October 12, 2019; Revised May 9, 2020; accepted May 21, 2020).

\begin{abstract}
The present work treats anaerobic digestion as an alternative way for olive pomace treatment for energy and fertilizer production. Physico-chemical tests were conducted to identify the olive pomace biochemical methane potential (BMP). Effects of critical parameters, including, $\mathrm{C} / \mathrm{N}$ ratio, dry matter and total volatile matter of the samples were carried out in order to optimize biogas composition. The first tests performed using $4 \mathrm{~g}$ of pomace oil, with a mass ratio of inoculum: feedstock of $1: 1$, show a stable biogas production after 48hrs that can attain up to $200 \mathrm{ml} /$ day. The total volume of biogas produced was $500 \mathrm{ml}$ containing $51 \%$ wt methane.
\end{abstract}

Keywords: anaerobic digestion, biogas, olive pomace.

\section{Introduction:}

Recently, an increasing interest for biogas energy production has been seen globally ${ }^{1}$. A major contribution to this was noticed in North African region, especially in Tunisia, which is related to the valorization of residues from the olive industry as an ecological and economical source. Indeed, it would allow the protection of the environment and the control of energy which represents one of the pillars of sustainable development and concerns a major part to the world.

The depletion of fossil energy resources and the awareness of the impact of greenhouse gas emissions on the environment ${ }^{2)}$ have been the two main reasons for looking for alternative sources of energy.

Produced gas will be used for various energetic purposes, such as heat, combined heat and power or as a vehicle fuel, which can generate benefits on environmental and economic plans ${ }^{3)}$.

Population growth generates different types of wastes all over the world. Organic wastes decomposition causes large quantities of greenhouse gas emissions. Olive is a staple food in the Mediterranean countries. It widely grows in many countries of Africa, Europe and Asia.

International Olive Council estimated world olive production in 2018 to be around 6000000 tons $^{4)}$. Out of this, olive oil production represents $20 \%$, while $33 \%$ are generated in form of olive pomace ${ }^{5)}$.

The pomace is the solid residue from pressing that is formed of pulp and olive stones. This waste contains on average of $28.5 \%$ water, $41.5 \%$ hull, $21.5 \%$ pulp and $8.5 \%$ oil. The olive pomace is composed of a lignocellulosic matrix (cellulose, hemicelluloses and lignin), phenolic compounds, uronic acids, and oily residues ${ }^{5), 6)}$.

The main difficulties to treat this solid waste are related to their high phenolic compounds content which makes them toxic for the environment. For example, Tunisia is among the top four olive oil producing countries. Its production represents a yearly average of 200000 tons of olive pomace waste ${ }^{7)}$. These wastes are not used as Fertilizers because of their high acidity and they are not used for animals feed because of their toxicity and to the high content of glycoside compounds $^{8}$. That is why farmers find a serious problem to deal with this waste ${ }^{9}$, which is linked to the formation of nauseous odors and contaminated air, a source of diseases for humans and toxic for the surrounding ecosystems $^{10)}$.

On the other hand, a significant percentage of oil remains in the pomace ${ }^{11)}$. These oils can be recovered by chemical extraction using a solvent ${ }^{12)}$ where highly acid oil is produced. The remaining pomace is called exhausted pomace. Because of its high acidity, olive pomace oil is often valorized in non-alimentary uses such as soap production.

Tunisia attaches great importance to olive oil industry and is more concerned by environmental issues related to it. As the sustainability is one of the priorities in its economic and social development plans ${ }^{9}$, interest is growing in sustainable management of these wastes.

Anaerobic digestion of olive pomace waste could be a sustainable solution that makes it possible to generate income while dealing with wastes from the olive industry. 
Anaerobic digestion is a complex biological process of decomposing biomass by bacteria that is activated in the absence of oxygen. At the end of the process, biogas and fertilizer are formed. A great deal of scientific research on similar raw materials shows the effectiveness of these treatments.

In this study, anaerobic digestion of raw and exhausted OP is studied in order to evaluate their stoichiometric, theoretical and biochemical methane production potentials ${ }^{13)}$.

\section{Materials and methods}

\subsection{Feedstock sampling and pretreatment}

Raw and exhausted olive pomace samples were furnished by ABOU EL WALID industry, where the raw olive pomace is treated with hexane in order to recover two products, a solid: the exhausted olive pomace and a liquid: olive pomace oil.

Raw and exhausted olive pomace (ROP and EOP, respectively) were grated using a mixer and then dried at $105^{\circ} \mathrm{C}$ and stored at room temperature in sealed containers.

\subsection{Samples characterization}

A fine powder is obtained by milling dry OP using a Retsch MM vibratory mill B117130 ball mill.

Thermogravimetric analysis (TGA) was performed using the Setsys Evolution device in order to determine its composition. To do so, a first plateau was set at $105^{\circ} \mathrm{C}$ to determine humidity content. Then tree consecutive plateaus at $250^{\circ} \mathrm{C}, \quad 300^{\circ} \mathrm{C}, \quad 500{ }^{\circ} \mathrm{C}$ to quantify hemicellulose, cellulose and lignin respectively.

Elementary analysis or estimation in $(\mathrm{CHNO} / \mathrm{S})$ is done using a Flash 1112 Series analyzer.

The protein content was calculated by multiplying by 6.25 the total nitrogen obtained from the CHNS-O analysis extract ${ }^{14)}$.

Total solids (TS), volatile solids (VS) and ash content of the samples were also according to AFNOR standard ${ }^{15)}$.

\subsection{Determination of total lipids}

Total lipid extraction was performed using solvents to extract oil from the samples using C. Gerhardt's SOXTHERM® rapid method. The total lipid content was determined using Equation 2 from the initial weight of the sample and the weight of the cylindrical glass vessel before and after extraction.

$$
\% \text { Lipid content }=\frac{W 2-W 1}{W 3} * 100
$$

Where W1 = Weight of the container with pumice stone before extraction;

W2 = Weight of the container containing the lipid extract and the pumice;

W3 = Weight of the sample.

\subsection{Estimation of the stoichiometric methane (B0)}

\section{yield of the samples}

The empirical formula $\left(\mathrm{C}_{\mathrm{a}} \mathrm{H}_{\mathrm{b}} \mathrm{O}_{\mathrm{c}} \mathrm{N}_{\mathrm{d}} \mathrm{S}_{\mathrm{x}}\right)$ was determined on the basis of the elemental composition $(\mathrm{C}, \mathrm{H}, \mathrm{N}, \mathrm{S}, \mathrm{O})$ of the samples ${ }^{16)}$. The stoichiometric methane (B0) yield of the samples was determined according to Equations 2 and 3 established by Paul W et al. ${ }^{17)}$. The results are not precise, give maximum potential for methane and will often be much too optimistic because it does not take into account the effects of inhibitors, non-degradable materials, nor the energy demand of microbes.

$$
\begin{aligned}
& \underset{\mathrm{C}_{\mathbf{a}} \mathrm{H}_{\mathbf{b}} \mathrm{O}_{\mathbf{c}} \mathbf{N}_{\mathbf{d}}+\frac{(4 a-b-2 c+3 d)}{4}}{\frac{(4 a-b+2 c+3 d)}{8} \mathrm{CO}_{2}+\mathrm{d} \mathbf{N H}_{3}} \underset{\mathrm{H}_{2} \mathrm{O}}{\longrightarrow} \frac{(4 a+b-2 c-3 d)}{8} \mathrm{CH}_{4}+ \\
&
\end{aligned}
$$

In this Equation, under the assumption that the organic matter is stoichiometrically converted to methane, carbon dioxide and ammonia.

So the specific methane yield expressed in milliliters of $\mathrm{CH}_{4}$ per gram of volatile solids (VS) can therefore be calculated as follows:

$$
\mathrm{B}_{0}=\frac{1}{8} *\left(\frac{4 a+b-2 c-3 d}{12 a+b+16 c+14 d}\right) * \mathrm{Vm}
$$

$\mathrm{Vm}$ is the molar volume of methane under normal pressure and temperature.

\subsection{Theorical methanogenic potential's evaluation}

Using the composition of the substrate and the degree of biodegradability, the yield of biogas / methane production is improved ${ }^{18)}$.

Depending on the concentration (in\% TS) of carbohydrates, proteins and lipids in the substrate, the maximum theoretical yield (BT) of the samples is determined using equation 4

$$
\mathrm{B}_{\mathrm{T}}=\frac{1}{100}(A \times C l+B \times C p+C \times C c)
$$

\footnotetext{
$\mathrm{A}=$ the specific methane yields of lipids $=1.014$

$\mathrm{B}=$ the specific methane yields of proteins $=0.496$

$\mathrm{C}=$ the specific methane yields of carbohydrates $=0.415$

$\mathrm{Cl}=$ concentrations of the lipids
} 
$\mathrm{Cp}=$ concentrations (based on \% TS) of the proteins

And $\mathrm{Cc}_{\mathrm{c}}=$ concentrations (based on \% TS) of the carbohydrates

\subsection{Evaluation of biochemical potential of methane (BMP)}

The realization of the biochemical potential of methane was according to the protocol developed by Angelidaki et al. ${ }^{19)}$ with minor modifications. The Table1 shows the BMP flasks composition

Table 1. The composition of BMP flasks

\begin{tabular}{|l|l|l|}
\hline Parameters & ROP & EOP \\
\hline Volatiles solid Substrate (g) & 1.71 & 1.71 \\
\hline Volatile solid Inoculum (g) & 1.71 & 1.71 \\
\hline Water (ml) & 4 & 2 \\
\hline C/N ratio & 55 & 49 \\
\hline $\mathrm{pH}$ & $7.1 \pm 0.1$ & $6.9 \pm 0.5$ \\
\hline
\end{tabular}

The fermentation of olive pomace was under anaerobic conditions at a constant temperature of $37^{\circ} \mathrm{C}$. Control of the volume of gas is done by graduated bottles via the Mariott method ${ }^{10)}$.

\section{Results and discussions}

In the biomethane production process, the composition of the raw material which plays an important role for the determining of the methanogenic potential as illustrated in the equation $\mathrm{B}_{\mathrm{T}}$. The biomass characterization is shown in Table 2.
Table2: Biomass characterization

\begin{tabular}{|c|c|c|}
\hline $\begin{array}{c}\text { Samples' } \\
\text { Parameter* }\end{array}$ & ROP & EOP \\
\hline Dry Matter (\%) & 4.6 & 4.2 \\
\hline $\begin{array}{c}\text { Volatile Solids } \\
\text { (\%) }\end{array}$ & $97.00 \pm 0,01$ & $90.00 \pm 0,00$ \\
\hline Lipids (\%) & 6.3 & 2 \\
\hline Proteins (\%) & 5.13 & 6 \\
\hline $\begin{array}{c}\text { Hemicellulose } \\
\text { (\%) }\end{array}$ & 19.8 & 18.9 \\
\hline Cellulose (\%) & 22.77 & 22.12 \\
\hline Lignin (\%) & 17.8 & 18.6 \\
\hline
\end{tabular}

*All data are given as a percentage of dry matter (DM).

\subsection{The effect of the $\mathrm{C} / \mathrm{N}$ ratio on methane production}

The $\mathrm{C} / \mathrm{N}$ ratio calculated in the ROP and EOP samples makes it possible to conclude that this raw material can not be used as the sole substrate for anaerobic digestion. $\mathrm{C} / \mathrm{N}$ values are not in the optimal range, ie $20-30^{20}$. For both ROP and EOP samples, the $\mathrm{C} / \mathrm{N}$ ratio is high, 55.25 and 49.33 respectively, indicating that the nitrogen deficiency of olive pomace could lead to a decrease in the efficiency of methane production due to deactivation of methanogens and possible risks of failure of the whole process $^{21)}$. However, attention must be paid to the nitrogen deficiency of olive pomace, and this nitrogen deficiency must be compensated for by a substrate with high nitrogen content, like cattle manure waste, or spent coffee ground are good biological sources of nitrogen 22$), 23)$.

\subsection{Stochiometric potential: Establishment of the empirical formula}

The elemental composition of the different samples made it possible to establish their empirical formula according to the method defined by Murphy et al. ${ }^{24)}$. Table 3 shows the elemental composition of the different samples. 
Table 3: Elemental composition and Atomic constituents of the samples

\begin{tabular}{|c|c|c|c|c|c|c|}
\hline \multirow{5}{*}{ Sample } & $\begin{array}{c}\text { Chemical } \\
\text { element }\end{array}$ & $\begin{array}{c}\text { Elemental } \\
\text { composition } \\
\text { (\% DM) }\end{array}$ & $\begin{array}{c}\text { Mass } \\
\text { contribution of } \\
\text { each } \\
\text { element(g/L) }\end{array}$ & $\begin{array}{c}\text { Atomic } \\
\text { mass }\end{array}$ & $\begin{array}{c}\text { Ratio of mass } \\
\text { contribution } \\
\text { by the atomic } \\
\text { mass }\end{array}$ & $\begin{array}{c}\text { Number of } \\
\text { moles/ mole }\end{array}$ \\
\hline \multirow{7}{*}{ ROP } & Carbon & $45.31 \pm 0.06$ & 453 & 12 & 37.75 & 66 \\
\cline { 2 - 7 } & Hydrogen & $5.54 \pm 0.06$ & 55 & 1 & 55 & 96 \\
\cline { 2 - 7 } & Nitrogen & $0.82 \pm 0.06$ & 8 & 14 & 0.57 & 1 \\
\hline & Oxygen & $41.51 \pm 0.06$ & 415 & 16 & 25.93 & 45 \\
\hline
\end{tabular}

The following empirical formulas emerge: $\mathrm{C}_{66} \mathrm{H}_{96} \mathrm{O}_{45} \mathrm{~N}$ and $\mathrm{C}_{62} \mathrm{H}_{94} \mathrm{O}_{44} \mathrm{~N}$ respectively for raw olive pomace (ROP) and exhausted olive pomace (EOP). By integrating respectively, the number of atoms and the concentration of organic compounds of each sample in the formulas

established in equations 3 and 4, the values BO and BT obtained are shown in the Table 4.

Table 4: Results of maximum stoichiometric $\mathrm{B}_{0}$ and theoretical BT yields of samples.

\begin{tabular}{|l|l|l|l|l|}
\hline Samples & $\begin{array}{l}\text { Empirical } \\
\text { formula }\end{array}$ & $\begin{array}{l}\mathbf{B}_{\mathbf{0}}(\mathbf{m l} \\
\mathbf{C H}_{4} \\
\left.\mathbf{g}^{-1} \mathbf{V S}\right)\end{array}$ & $\begin{array}{l}\mathbf{B}_{\mathbf{T}}(\mathbf{m l} \\
\mathbf{C H}_{\mathbf{4}}\end{array}$ & $\mathbf{B M P ( m l}$ \\
$\left.\mathbf{g}^{-1} \mathbf{V S}\right)$ & $\mathbf{C H}_{\mathbf{4}}$ \\
$\left.\mathbf{g}^{-1} \mathbf{V S}\right)$ \\
\hline ROP & $\mathrm{C}_{66} \mathrm{H}_{96} \mathrm{O}_{45} \mathrm{~N}$ & 686 & 247 & 95 \\
\hline EOP & $\mathrm{C}_{62} \mathrm{H}_{94} \mathrm{O}_{44} \mathrm{~N}$ & 672 & 199 & 54 \\
\hline
\end{tabular}

Conforming to the results in the table 3 , the theoretic methane potential $\left(\mathrm{B}_{\mathrm{T}}\right)$ is 2.5 and 4 times higher than BMP of ROP and EOP respectively. This effect can be attributed to the accessibility of carbohydrates to methanogenic microorganisms. Hence the need for mechanical pre-treatment and chemical pre-treatment, in order to improve this accessibility ${ }^{25)}$.

\subsection{Result of the stochiometric and theoretical}

\section{methanogenic potential}

According to results, we observed that the samples had significant differences in stoichiometric and theoretical methane yields. Those differences are mainly related to lipids content of ROP that enhance its biomethane potential.

The main reason of these results could be summarized in the specific methane percentages extracted from Angelidaki et al. ${ }^{26)}$ to calculate the theoretical potential $\mathrm{B}_{\mathrm{T}}$ are linked to lipids, proteins and carbohydrates determined by empirical formulas of the substrates used. It is crucial to mention that the sample's organic matter content can change as a function of time, climate or region and this factors can significantly affect the theoretical potential.

\section{Conclusion}

The olive pomace is a perfect substrate for micro-organisms, it is necessary to adjust some parameters such as the $\mathrm{pH}$ and the $\mathrm{C} / \mathrm{N}$ ratio by providing a source of nitrogen in order to favor the methanogenic potential.

The comparison between the stoichiometric yield, and the theoretical yield, gives that, the BMP is 0.4 and 2.5 times less than theoretic methane potential of ROP and 
EOP respectively. This effect can be attributed to the accessibility of carbohydrates to methanogenic microorganisms.

However, these different studies show that the pretreatment of olive pomace allows increasing the methane yield during anaerobic digestion. Hence the need for mechanical pre-treatment and chemical pre-treatment, in order to enhance the energetic outcome of anaerobic digestion of olive pomace.

\section{Acknowledgements}

The authors greatly acknowledge Abou el Walid industry in Tunisia for providing of samples.

\section{Nomenclature}

$R O P$ raw olive pomace

EOP exhausted olive pomace

$B T$ the maximum theoretical yield

A the specific methane yields of lipids

$B$ the specific methane yields of proteins

$C$ the specific methane yields of carbohydrates

$\mathrm{Cl}$ concentrations of the lipids

Cp concentrations (based on \% TS) of the proteins

Cc concentrations (based on \% TS) of the carbohydrates

BO the maximum methane stoichiometric

$\mathrm{Vm}$ the molar volume of methane

\section{References}

1) I. Alhamid, E. Kusrini, D. Supramono, M.I. Alhamid, S. Pranata, D. Wilson, and A. Usman, "Effect of polypropylene plastic waste as co- feeding for production of pyrolysis oil from palm empty fruit bunches effect of polypropylene plastic waste as co-feeding for production of pyrolysis oil from palm empty fruit bunches," EVERGREEN Joint Journal of Novel Carbon Resource Sciences \& Green Asia Strategy, 6 (1) 92-97 (2019).

2) \& S. Pal, A., Uddin, K., Thu, K., "Environmental Assessment and Characteristics of Next Generation Refrigerants Next Generation Refrigerants,” 2018.

3) Y.M. Sadak, M. Makhlouf, and S.E.L. Amrouni, "Évaluation qualitative et possibilités de valorisation biologique de la biomasse oléicole reprise dans le sahel tunisien,” JORNAL OF NEW SCIENCES, 18 (4) 668-678 (2015).

4) "World catalogue of olive varieties International Olive Oil Council.,” 2017.

5) T.F.A.O. Productionsant, E. Martilotti, I. Nefzaoui, and T. Zo, "Utilisation des sous-produits de l' olivier en alimentation animale dans le bassin
Méditerranéen,” 2011.

6) S. Sciencedirect, "Biocatalysis and agricultural biotechnology optimization of immobilization conditions of thermomyces lanuginosus lipase on olive pomace powder using response surface methodology,” $1 \quad 39-44 \quad$ (2012). doi:10.1016/j.bcab.2011.08.009.

7) F. Pagnanelli, C.C. Viggi, and L. Toro, “Applied surface science development of new composite biosorbents from olive pomace wastes," Applied Surface Science, 256 (17) 5492-5497 (2010). doi:10.1016/j.apsusc.2009.12.146.

8) F. Sellami, R. Jarboui, S. Hachicha, K. Medhioub, and E. Ammar, "Co-composting of oil exhausted olive-cake, poultry manure and industrial residues of agro-food activity for soil amendment," 99 1177-1188

(2008). doi:10.1016/j.biortech.2007.02.018.

9) G. Perkins, T. Bhaskar, and M. Konarova, "Process development status of fast pyrolysis technologies for the manufacture of renewable transport fuels from biomass," Renewable and Sustainable Energy Reviews, 90 (July 2017) 292-315 (2018). doi:10.1016/j.rser.2018.03.048.

10) Y. Furutani, K. Norinaga, and S. Kudo, "Current situation and future scope of biomass gasification in japan current situation and future scope of biomass gasification in japan,” 4 (4) 24-29 (2017).

11) A.R. Tekin, and A. Cos, "Biogas production from olive pomace biogas production from olive pomace," $3449 \quad$ (November) (2000). doi:10.1016/S0921-3449(00)00067-7.

12) N. Benyahia, and K. Zein, "Analyse des problèmes de $\mathrm{l}$ ' industrie de $\mathrm{l}$ ' huile $\mathrm{d}$ ' olive et solutions récemment développées,” (2003).

13) S. Kitjanukit, "Attitude toward bioremediation-related technology and relation with company social responsibility,” EVERGREEN Joint Journal of Novel Carbon Resource Sciences \& Green Asia Strategy, 06 (03) 240-245 (2019).

14) J.N.C. Whyte, "Biochemical composition and energy content of six species of phytoplankton used in mariculture of bivalves," 60 231-241 (1987).

15) A. Maritchù, and C.E. Marcato, "Open archive toulouse archive ouverte ( oatao ) particle size and metal distributions in anaerobically digested pig slurry,” 99 2340-2348 (2008).

16) P.Gerike, "The biodegradability testing of poorly water soluble compounds," Chemosphere, 13 (I) 169-190 (1984).

17) P.W. Unger, "Managing Agricultural Residues," 1994.

18) J. Kuo, and J. Dow, "Biogas production from anaerobic digestion of food waste and relevant air quality implications," Journal of the Air \& Waste Management Association, 67 (9) 1000-1011 (2017). doi:10.1080/10962247.2017.1316326. 
19) I. Angelidaki, M. Alves, D. Bolzonella, L. Borzacconi, J.L. Campos, A.J. Guwy, S. Kalyuzhnyi, P. Jenicek, and J.B. Van Lier, "Defining the biomethane potential ( bmp ) of solid organic wastes and energy crops: a proposed protocol for batch assays," 927-934 (2009). doi:10.2166/wst.2009.040.

20) U. Marchaim, "Biogas processes for sustainable development,” 2004.

21) M. Kayhanian, "Ammonia inhibition in high-solids biogasification : an overview and practical solutions," (April 1999) (2014). doi:10.1080/09593332008616828.

22) N. Ali, A.K. Kurchania, and S. Babel, "Bio-methanisation of jatropha curcas defatted waste,” 2 (3) 38-43 (2010).

23) F. Battista, D. Fino, and G. Mancini, "Optimization of biogas production from coffee production waste," Bioresource Technology, 200 884-890 (2016). doi:10.1016/j.biortech.2015.11.020.

24) D.M. Murphy, "Unbiased loss development factors," p.183 (1994).

25) A.K. Kumar, and S. Sharma, "Recent updates on different methods of pretreatment of lignocellulosic feedstocks: a review," Bioresources and Bioprocessing,

(2017). doi:10.1186/s40643-017-0137-9.

26) I. Angelidaki, and W. Sanders, "Assessment of the anaerobic biodegradability of macropollutants," 117-129 (2004). 